\title{
The impact of customer relationship management on enhancing the customers loan satisfaction in commercial banks in Cameroon.
}

\author{
Li Zhihong and Andre Djondzo \\ Department of Decision, School of Business Administration, South China University of Technology, China
}

\begin{abstract}
CRM is a strategy and business process encompassing many technologies by which firms acquire, manage, and serve customers. The goal of a bank implementing a CRM strategy is to gather and organize both data and knowledge about customers in order to provide support to advisers, salesforce, customer service representatives, and probably end customers.

Therefore, this research examined the impact of customer relationship management activities in the commercial banks in Cameroon, in order to evaluate the customer satisfaction on loan acquisition.

CRM solutions are very much in high demand, especially since financial services institutions want to provide as much transparency and customized service to customer as possible in order to enhance their satisfaction. CRM systems automate critical sales, marketing, and client service activities at a financial institution.

Keyword: banks, customer relationship management, customer satisfaction, loan acquisition

DOI: $10.7176 / \mathrm{EJBM} / 11-12-23$

Publication date: April $30^{\text {th }} 2019$

\section{Background}

Customer relationship management (CMR) is a primary process or philosophy used to manage the organization's interactions with its customers. Its using a combination of customer's needs and marketing for relationship building in order to develop stronger relationship with customers, users and the all the issues related to sale and financial transactions. Nowadays, banks and other financial institutions are dealing with several challenges including global competition for deposits, loans, and underwriting fees; increasing customer demands; shrinking profit margins; and the need to keep up with the new technologies (SAP AG, 2002). According to Onut et al., (2006), banks and several other financial service providers have realized the importance of Customer Relationship Management $(\mathrm{CRM})$ and its potential to help them to acquire new customers, retain existing ones, and maximize their lifetime value. Therefore, CRM considered as a strategic business and process rather than a technical issue (Dowling, 2002). Banks have also realized that CRM is the only solution to help them to maintain a long-term relationship with their customers. Moreover, it's important to recognize that the main goal of CRM process is organizational performance, which is defined by considering as important the customer satisfaction. (Haridan \&Venkatesh, 2011) stated that CRM has a long term aim which is to enhance the quality and to improve the interface with the customer which lead toward customer satisfaction. Satisfaction is a crucial concern for both customer and organizations including financial institutions such as commercial banks. In the competitive economy, customer's satisfaction has come under limelight due to stiff competition where organizations are trying to take competitive advantage through the human factor and customers (Singh et al, 2011). The importance of customer satisfaction in the banking industry can't be discarded while the satisfied customers were the free advertising tools for the company. Enhancing customer satisfaction is critical because it is a key to business success of any banking institution, and its easier and more profitable to sell and serve present customers than finding new ones. This study tries to highlight the impact of customer relationship management on customers' satisfaction in loan acquisition in the commercial banks in Cameroon.
\end{abstract}

\section{Literature review}

Customer relationship management (CRM) systems are one of the components in many financial institutions' application maps. Although CRM solutions are not unique to one industry, they are still key technologies used to manage relationships with customers, whether customers are defined as financial services representatives, brokerage agents, or clients. According to Vella and Caruana (2012), CRM involves the management of an organization's interactions with its customers through analysis of customer history data with the aim of enhancing business relationships with the organization's clients in order to improve customer retention rates. Khodakarami and Chan (2014) point out that technologies used in CRM seek to automate processes in diverse areas such as management and analysis, customer support, marketing, and sales. Cho, et . al . (2013), investigate the impact of customer relationship management on customer satisfaction and loyalty. The study employed quantitative approach and base on 300 respondents. Their study shows that behavior of the employees is significantly related and contributed to customer loyalty compared to other elements of CRM i,e interaction management, relationship management and services quality. Kocoglue (2012), in his study titled customer relationship management and 
customer loyalty in the banking industry, conducted the study on a sample of 350 staff employed in all the branches in Denizili of T.C. Ziraat Bank. The study concluded that all elements of CRM i.e. customer database, learning customer needs and complaints, and providing solutions peculiar to customers are positively correlated with customer loyalty.

Khaligh et al. (2012) investigate the impact of CRM on customer loyalty and retention in the telecom industry in Iran. The data were collected from 200 Iranian telecom services users. Finding shows that commitment and vision of the management system is highly required for a successful CRM implementation, the structure of the strategy should be based on flexibility and explicitly of the policies especially pricing policies. These factors are very importance to increase customer loyalty and benefit of the firm (Khaligh et al.2012). Furthermore, Bhattachacharya (2011) stated that, CRM is implemented in an organization to reduce cost and increase company performance, which means profitability result through customer satisfaction and loyalty.

According to the conceptual framework proposed by Faed (2010), customer relationship management amplifies the relationships of customers and competitors in a firm to increase the share of the organization in marketplace by integration technology, procedures and people. The aim of CRM in this case is to maintain the customers and increase their satisfaction and loyalty and organization profit. Customer satisfaction and pleasing are two main elements in successful CRM implementations for retaining customer's loyalty to firm.

Moreover, Baran and Galka (2013) define the basic dimensions of CRM as the formation and maintenance of mutual loyalty between customers and the company, constructing customer interaction, use of direct techniques of marketing, and customer relationship personalization.

Generally, all elements of CRM are aimed at increasing the efficiency and reducing costs related to customer interactions; as well as improving labor efficiency and increasing decision-making speed.

Therefore, managing customer relationship is a strategic platform, which has become a focal point of research of many scholars and practitioners. CRM increased the ability of banks to better understand the actual needs of their clients and also helped them develop strategies for meeting their benchmark satisfaction.

Modern management sciences philosophy considers customer satisfaction as a baseline standard of performance and a possible standard of excellence for any business organization (Gerson, 1993). Customer satisfaction is one of the most important issues concerning business organization of all types. As Roch \& Allen (2007) state, "to understand the difference between customers attitudes and behaviors and how the relationship between them works is crucial for managers involved in any aspect of customer management, since attitudes show the customers satisfaction and behavior show customers' loyalty."

Customer satisfaction is one of the most important factors in business. When it comes to commercial banks, customer satisfaction level differentiates one bank from another, thus measuring customer satisfaction is exceedingly important. (Zopounidis, 2012, 37.). Customer satisfaction has been extensively researched in various industries in the marketing literature. Customer satisfaction can be determined by either subjective factors (e.g. customer needs, emotions) or objective factors (e.g. product and service features). Applying to the banking industry, there have been numerous studies that examined the attributes that clients expect regarding customer satisfaction. In this regard, Oduro (2013) investigated factors that determine customer satisfaction level in banking institutions. His study used factor analysis and found that three factors influence consumers' satisfaction level of the banks. These factors were found to be customer relation and service, staff competency and responsive and convenient banking.

The linkage between customer satisfaction and customer loyalty in the banking sector has also been widely researched (Sayani, 2015; Ehigie, 2006). Mukhtar et al. (2014) documented on customer satisfaction towards financial services of banks in Bahawalpur, Pakistan. The study used correlation analysis to check the intensity of relation of customer satisfaction with dimensions of service quality.

Loan acquisition in commercial banks is a contractual promise between two parties where one party, the creditor, agrees to provide a sum of money to a debtor, who promises to return the money to the creditor either in one lump sum or in parts over a fixed period of time Ergungor S. (2001). This agreement may include providing additional payments of rental charges (interest) on the funds advanced to the debtor for the time the funds are in the hands of the debtor. 
Loans could be secured, unsecured or demanded. Secured loans are collateralized whereas unsecured loans are collateral free.

\section{Research model and Hypotheses}

Research model

Various registers of customer relationship contribute to create customer satisfaction. Most of such tools are considered by most Cameroonian banks, like able to foster customer satisfaction. This study investigate the impact of CRM dimensions on customers loan acquisition that enhancing customer satisfaction in the banks in Cameroon. (Sun, K. A., \& Kim, D. Y. (2013)

The literature review that was use help to propose a model which reflect the main elements of CRM that are able to create customer satisfaction as show in figure.

Figure 1 shows that CRM elements have an independent variable represented on the model with four mains elements: service quality, CRM structure, customer database, technology based CRM. At the same time, the dependent variable is represented by two main elements: loan acquisition and customer satisfaction.

\section{Fig.1. Proposed conceptual framework}

\section{Independents variables dependent variables}

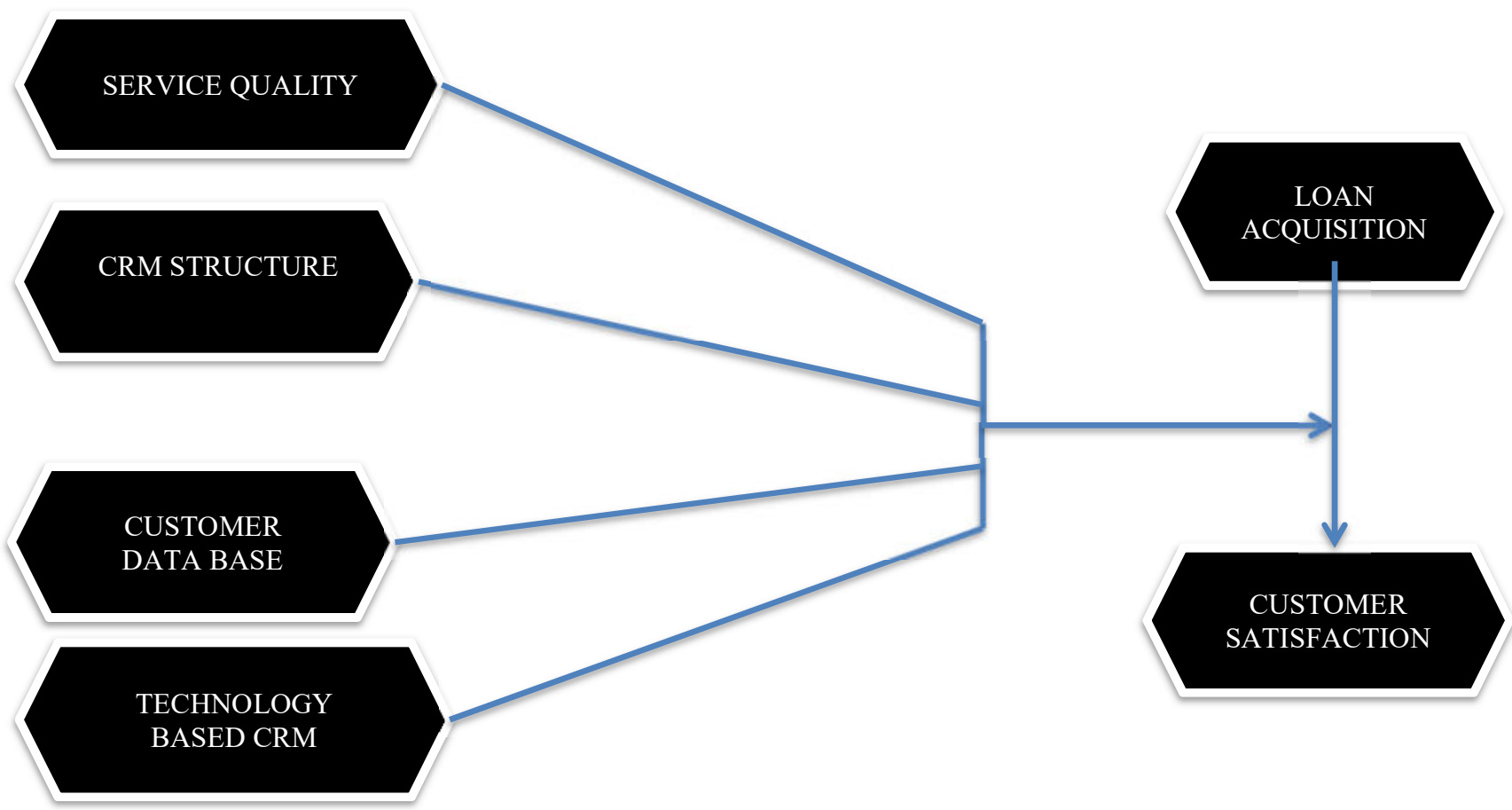

\section{Research hypotheses}

Based on related literature review and many empirical evidence conducted by many researchers in developed countries context, research hypothesis can be formulated as follows:

H0: There is no statistical significant relationship between customer relationship management and customer loan satisfaction in commercial banks in Cameroon

H1: There is a positive relationship between CRM system organization and loan acquisition

H2: There is a positive relationship between service quality and loan acquisition 
H3: There is a positive relationship between customer database and loan acquisition

H4: There is a positive relationship between technologies based CMR and loan acquisition.

Taking into consideration the five previous hypotheses to test each of the four CRM dimensions impact on loan acquisition, we, therefore, set the following hypothesis to test CRM impact on enhancing loan acquisition:

H5: There is a positive relationship between CRM and loan acquisition

\section{Research methodology}

The research design proposed for this study is descriptive nature. The research used a questionnaire survey method for collecting the primary data.

There are 51 banks and financial institutions in Cameroon, and more than 5000 employees. The population in this study is selected among the employees of foreign and local commercials bank, around 1470 employees. The researcher based on the sample size equation to determine the minimum sample size as follow.

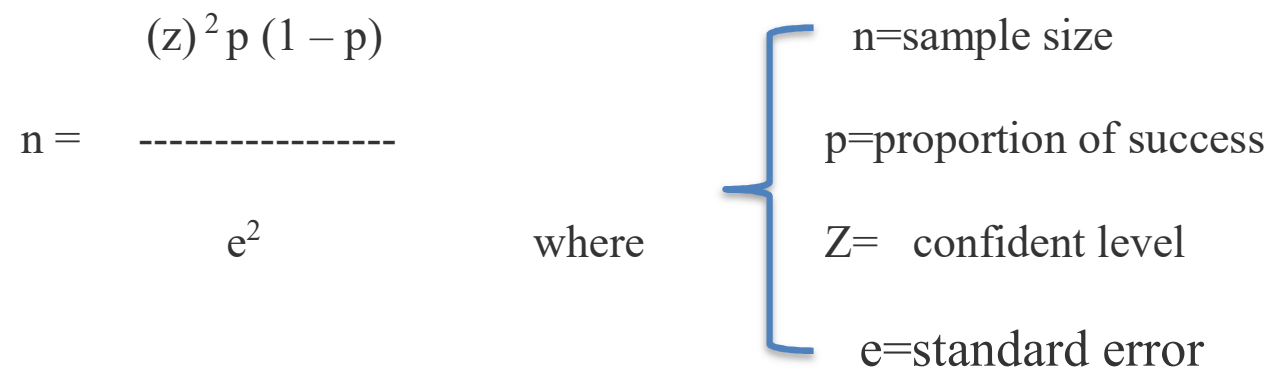

Based on this equation, the minimum sample size is 165 employees in the selected banks in Cameroon.

Simple random sampling was the sampling technique used to select 11 employees each bank who were given a questionnaire to fill.

Employees from a total of 15 selected commercial banks formed the respondents and were, therefore, covered for study. This study employed an exploratory research design and quantitative technique. The survey was conducted in Yaoundé and Douala. Primary data were collected using self-administered questionnaires. This survey questionnaire contained two parts; the first part was related to the respondents' demographic information, the second part consisted of the four dimensions of CRM, which were connected with the loan acquisition and customers satisfaction. Moreover, secondary data from sources such as research reports and publications on the topic were complemented to understand the phenomenon better.

Respondents were asked to rate items on a five-point Likert scale. The scale ranges from1 (strongly disagree) to 5 (strongly agree) was used to measure the loan satisfaction as related to CRM dimensions. Therefore, this study used: customer's managers, credit analyst or bank manager as target population and determine their sample size based on the sample size determination formula.

Respondents were chosen from these three key positions because they are

knowledgeable on both the bank practices of various CRM dimensions and the customer satisfaction as well. 
Finally, the developed research hypotheses constructed for the study were tested using correlation and regression analysis as the statistical tool. This was undertaken to determine the relationships between the dependent and the various independents variables using SPSS

\section{Data analysis and discussion}

In this study, the assumptions based on CRM practices and their impact on loan acquisition and customer's satisfaction in commercial banks in Cameroon. The data analysis is carried out by using the statistical package for social sciences (SPSS). Under CRM practices, the researcher will address the extent to which the CRM practices affect or not the loan acquisition.

To test whether there is the relationship between the dependent variable (Loan acquisition) and independents variables (CRM dimensions: service quality, CRM structure, customer database, technology based CRM.), the correlation and regression analysis were used to analyze the correlation between variables, also to analyze the significant impact of CRM dimensions on loan acquisition.

\section{Graphs of synthetic percentages}

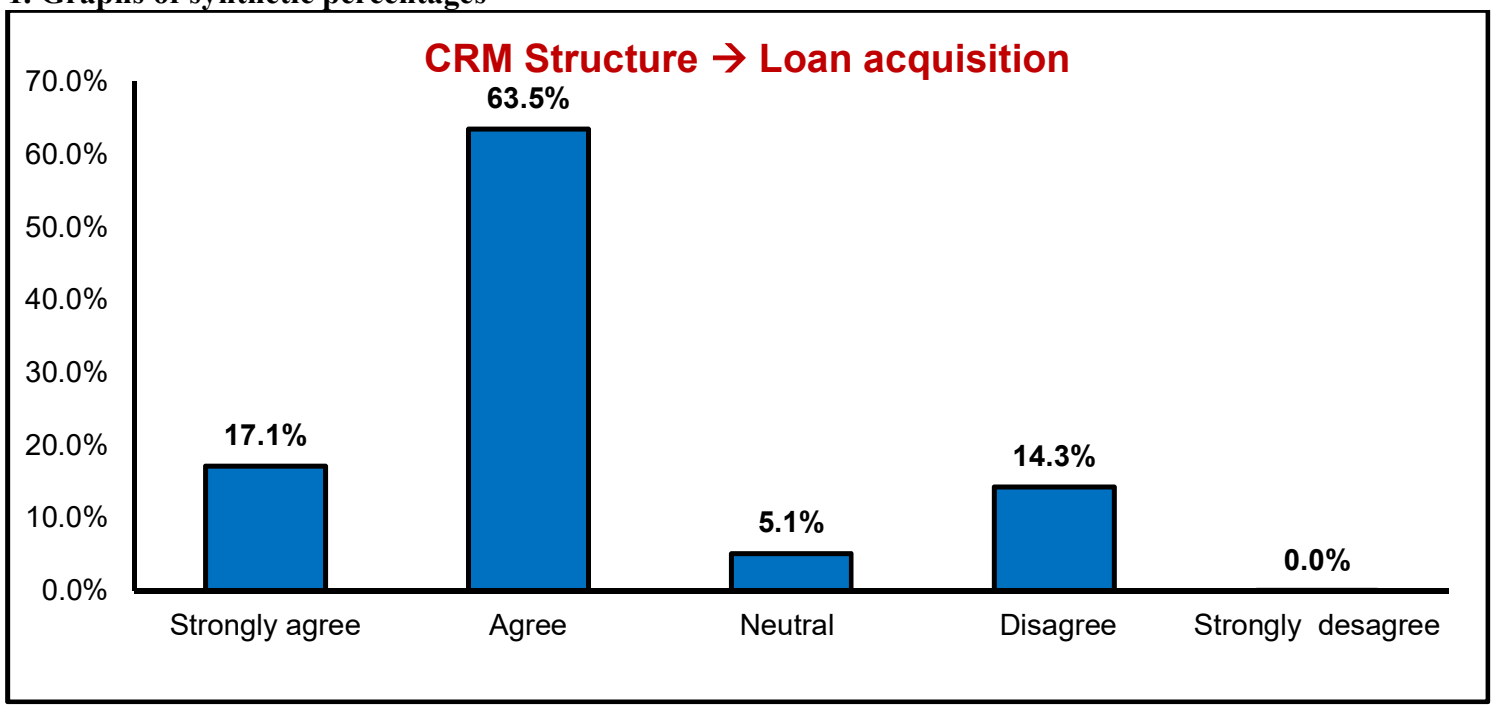

\begin{tabular}{|c|c|c|c|c|c|c|}
\hline Code & Denominated & Strongly agree & Agree & Neutral & Disagree & $\begin{array}{l}\text { Strongly } \\
\text { desagree }\end{array}$ \\
\hline ORGA & CRM Structure ( $\square$ A1) & $17,1 \%$ & $63,5 \%$ & $5,1 \%$ & $14,3 \%$ & $0,0 \%$ \\
\hline SQ & Service quality ( $\square$ A2) & $17,4 \%$ & $57,6 \%$ & $5,2 \%$ & $18,0 \%$ & $1,7 \%$ \\
\hline DATA & Customer database ( $\square$ A3) & $0,0 \%$ & $81,6 \%$ & $0,0 \%$ & $18,4 \%$ & $0,0 \%$ \\
\hline ТЕСН & $\begin{array}{l}\text { Technology based CRM } \\
\text { ( } \square \text { A4) }\end{array}$ & $24,8 \%$ & $61,6 \%$ & $0,0 \%$ & $13,5 \%$ & $0,0 \%$ \\
\hline CRM & $\begin{array}{l}\text { Customer relationship } \\
\text { management ( } \square \text { A.) }\end{array}$ & $15,1 \%$ & $65,9 \%$ & $2,6 \%$ & $16,0 \%$ & $0,4 \%$ \\
\hline
\end{tabular}




\section{Service quality $\rightarrow$ Loan acquisition}

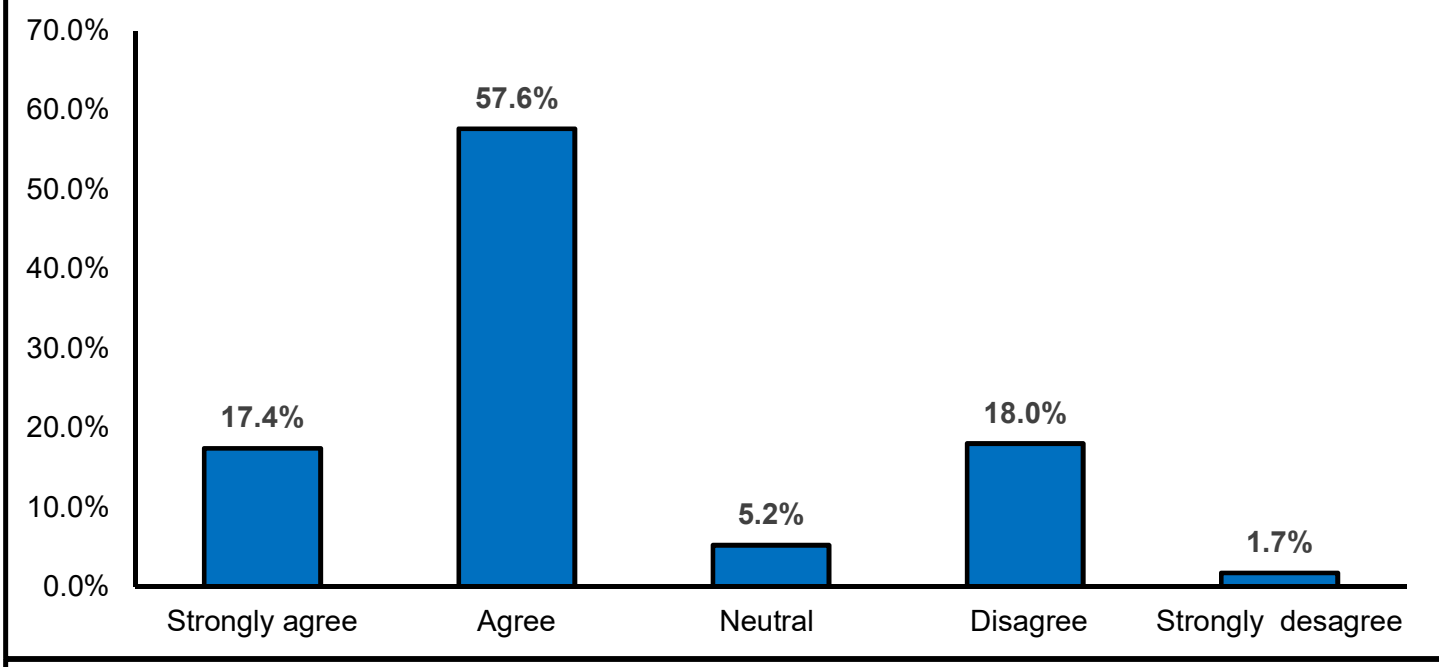

\section{Customer database $\rightarrow$ Loan acquisition}

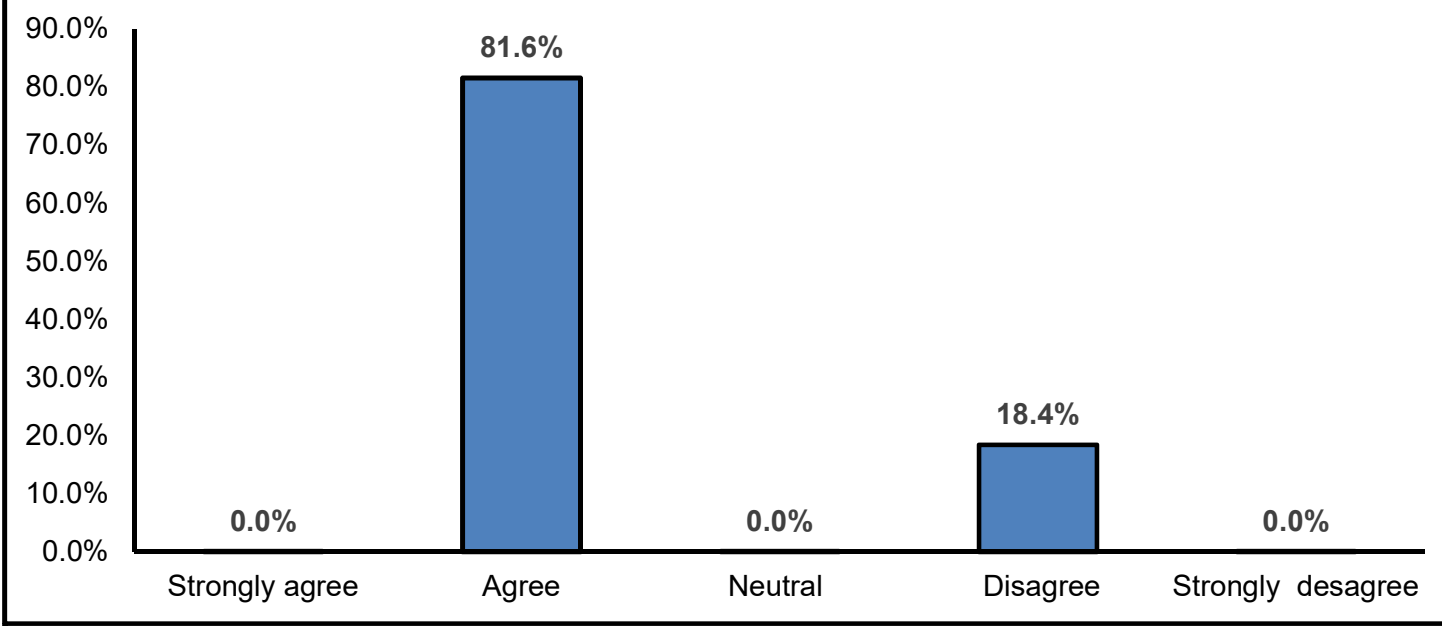

Technology based CRM $\rightarrow$ Loan acquisition

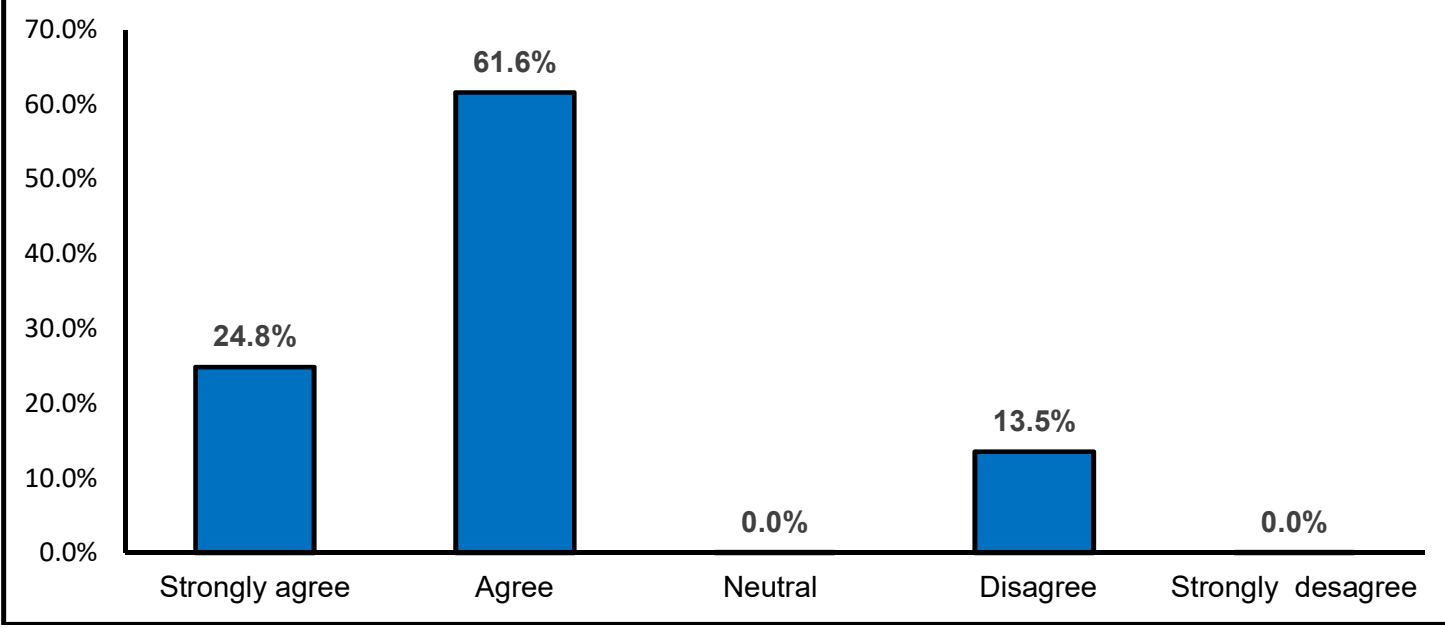




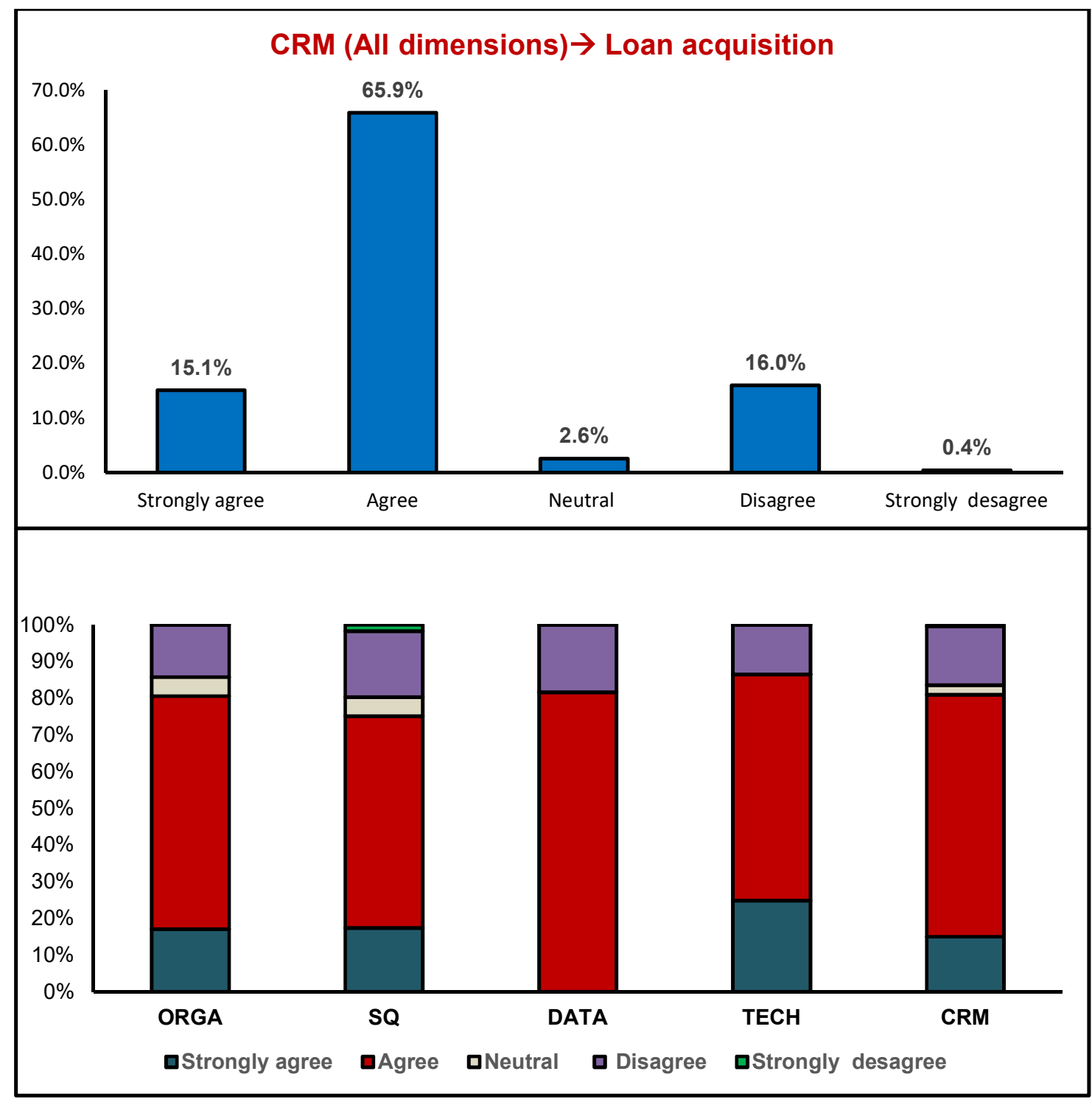

1. Determining the weghts of each answer in the likert scale and calculating item scores and record

\section{Weightings}

The weighting used is Borda defined by the score $\boldsymbol{\beta}_{\boldsymbol{h}}$. For modality $\mathbf{h}$, modalities and $\mathrm{i}$ : the rank of the modality in the ordinal scale considered.

$$
\left(\beta_{h}\right)=\frac{m-i}{m-1}=\frac{5-i}{4}, \text { because } \mathrm{m}=5
$$

The score vector is thus defined by $\boldsymbol{\beta}=\left(\mathbf{1}, \frac{\mathbf{3}}{\mathbf{4}}, \frac{\mathbf{1}}{\mathbf{2}}, \frac{\mathbf{1}}{\mathbf{4}}, \mathbf{0}\right)$

\begin{tabular}{|c|c|c|c|c|c|}
\hline Modalities' & Strongly agree & Agree & Neutral & Disagree & Strongly desagree \\
\hline Rank i & 1 & 2 & 3 & 4 & 5 \\
\hline Score & 1 & $3 / 4$ & $1 / 2$ & $1 / 4$ & 0 \\
\hline
\end{tabular}

The choice of Borda's score is justified by the fact that our answers are ordinal on a Likert scale. In addition, its standardization gives weightings between 0 and 1 . The scores of items and records are thus located in the interval $[0,1]$. 
The score of an item $\mathbf{j}$ of the score $r$ is given by :

$S_{j}^{r}=\sum_{h=1}^{m} \beta_{h, j} P_{h, j}$

where

$$
\left\{\begin{array}{c}
\beta_{h, j}: \text { the weighting of the modality } h \text { for the item } j \\
P_{h, j}: \text { the percentage of the mopdality } h \text { for the item } j \\
0 \leq \beta_{h, j}, P_{h, j}, S_{j}^{r} \leq 1 \\
j=1,2, \ldots, K ; h=1,2, \ldots, 5 ; r=1,2, \ldots, \text { avec } L=4
\end{array}\right.
$$

The record's score $\mathbf{r}$ is given by:

\begin{tabular}{|c|c|c|}
\hline Code & Wording of the Item or the Record & Mean score \\
\hline ORGA & CRM Structure ( $\square$ A1) & $\mathbf{0 , 7 1}$ \\
\hline ORGA1 & 1-Developing an environment with modern tools enhance customer satisfaction & 0,75 \\
\hline ORGA2 & $\begin{array}{l}\text { 2-Customer satisfaction tracking and complain management can increase customer } \\
\text { satisfaction }\end{array}$ & 0,77 \\
\hline ORGA3 & $\begin{array}{l}\text { 3-An effective service concept and operation procedure are helpful for customer loan } \\
\text { satisfaction }\end{array}$ & 0,69 \\
\hline ORGA4 & 4-Integrating organization resource to implement CRM improve customer satisfaction & 0,49 \\
\hline SQ & Service quality ( $\square \mathbf{A 2}$ ) & 0,68 \\
\hline SQ1 & 1-Providing banking prompt services on loan process increases customer satisfaction. & 0,58 \\
\hline SQ2 & 2-Dealing with customer confidentially foster customer satisfaction & 0,82 \\
\hline SQ3 & 3-Accuracy is essential for customer's satisfaction in banking loan acquisition. & 0,84 \\
\hline SQ4 & 4-Providing developed services by the bank is essential for customer satisfaction. & 0,32 \\
\hline SQ5 & 5-Spreading bank's branches is helpful for customers loan satisfaction. & 0,33 \\
\hline DATA & Customer database ( $\square \mathrm{A3}$ ) & 0,66 \\
\hline DATA1 & 1-Availability of bank customer database is essential for effective loan satisfaction & 0,58 \\
\hline DATA2 & 2-Upgrading customer database is effective to customer satisfaction. & 0,58 \\
\hline DATA3 & 3-The bank can get any information about customers when needed. & 0,68 \\
\hline DATA4 & $\begin{array}{l}\text { 4-Customer's all necessary information is easily obtained by officer to satisfy } \\
\text { customers. }\end{array}$ & 0,75 \\
\hline ТЕСН & Technology based CRM ( $\square$ A4) & 0,74 \\
\hline TECH1 & $\begin{array}{l}\text { 1-Information technology improve the banking loan process and customer loan } \\
\text { satisfaction }\end{array}$ & 0,82 \\
\hline ТЕСН2 & 2-IT is helpful to build better customer relationship and enhance customer satisfaction & 0,68 \\
\hline ТЕСН3 & 3-Implementing CRM system increase quickly decision making & 0,77 \\
\hline ТЕСH4 & 4-Information technology is helpful for the reliability of customer's information & 0,69 \\
\hline CRM & Customer relationship management ( $\square \mathbf{A}$.) & $\mathbf{0 , 7 0}$ \\
\hline
\end{tabular}

$S^{r}=\sum_{h=1}^{m} \sum_{j=1}^{K} \delta_{j} \beta_{h, j} P_{h, j}$

where $\left\{\begin{array}{l}\delta_{j}=\frac{n_{j}}{\sum_{j=1}^{K} n_{j}} \\ n_{j}: \text { the total number of item } j \\ 0 \leq S^{r} \leq 1\end{array}\right.$

Values of item scores and records

Characteristics of the records's scores 


\begin{tabular}{|l|l|l|l|l|}
\hline Record & Minimum & Maximum & mean & Standard deviation \\
\hline ORGA & 0,49 & 0,77 & 0,71 & 0,11 \\
\hline SQ & 0,32 & 0,84 & 0,68 & 0,23 \\
\hline DATA & 0,58 & 0,75 & 0,66 & 0,07 \\
\hline TECH & 0,68 & 0,82 & 0,74 & 0,06 \\
\hline
\end{tabular}

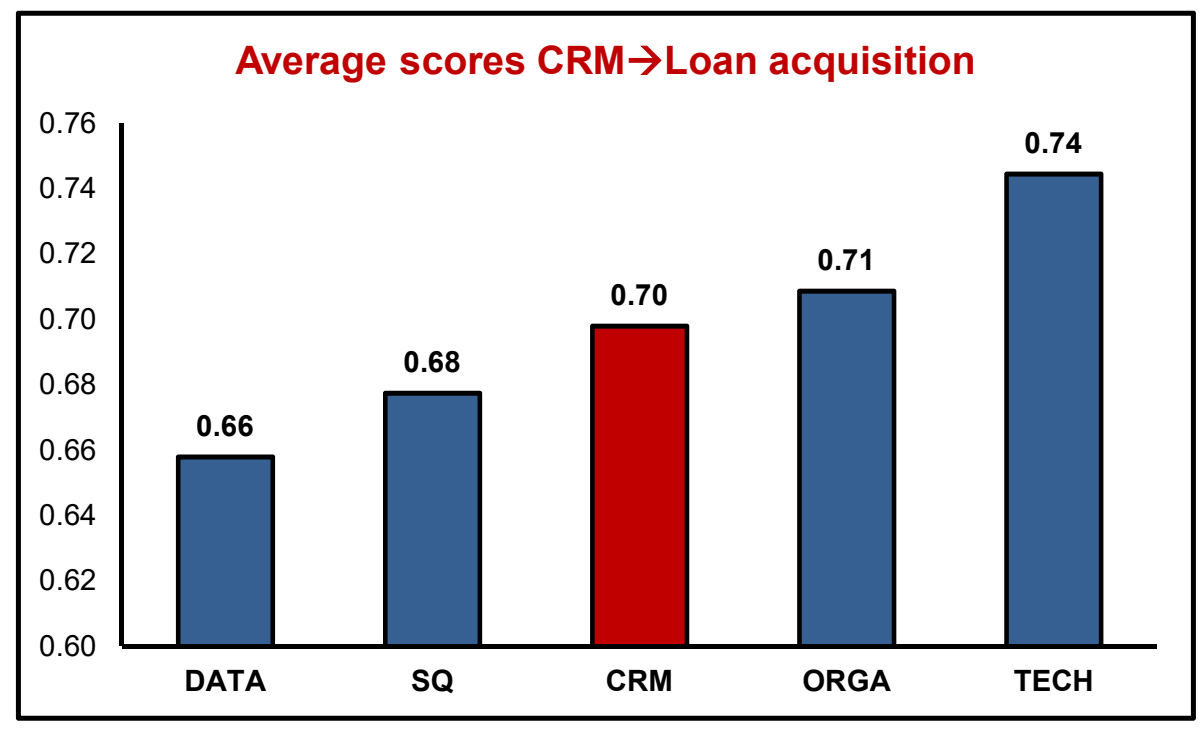

\section{Cronbach's Alpha of records}

the formula for a record $\mathrm{r}$ is:

$$
\begin{aligned}
\boldsymbol{\alpha}=\frac{K}{K-1}\left(\mathbf{1}-\frac{\sum_{j=1}^{K} \sigma_{Y j}^{2}}{\sigma_{X}^{2}}\right) \quad \text { Where } \mathbf{K} & =\text { the number of items, } \\
\sigma_{X}^{2} & =\text { is the variance of the total score } \\
\sigma_{Y j}^{2} & =\text { is the variance of item }
\end{aligned}
$$

\begin{tabular}{|l|l|l|l|l|}
\hline Record & $\mathbf{K}$ & \multicolumn{1}{|c|}{$\sum_{j=1}^{K} \boldsymbol{\sigma}_{\boldsymbol{Y} \boldsymbol{j}}^{2}$} & & Alpha $(\boldsymbol{\alpha})$ \\
\hline ORGA & 4 & 0,1628 & 0,4439 & $\mathbf{0 , 8 4}$ \\
\hline SQ & 5 & 0,1462 & 0,3830 & $\mathbf{0 , 7 7}$ \\
\hline DATA & 4 & 0,2308 & 0,8865 & $\mathbf{0 , 9 9}$ \\
\hline TECH & 4 & 0,1647 & 0,5119 & $\mathbf{0 , 9 0}$ \\
\hline
\end{tabular}

All Alpha coefficient are greater than 0.7 then, satified the condition of validation.

\section{3. significance tests of the scores of differents records}

It has been noted previously that the relationship between CRM and loan acquisition is positive when the average score $(\mu)$ of the record is strictly greater than 0.50 . Hence the need to perform the following hypothesis test:

$\left\{H_{0}: \mu \leq 0,50\right.$

$\left\{H_{1}: \mu>0,50\right.$

The results of Student's tests are presented in the below table : 


\begin{tabular}{|l|c|c|c|c|}
\hline \multicolumn{1}{|c|}{ Record } & mean score & $\begin{array}{l}\text { Standard deviation } \\
\text { of average score }\end{array}$ & T-Student & $\begin{array}{c}\text { P-value= } \\
\mathbf{P}(\mathbf{Z}>\mathbf{z})\end{array}$ \\
\hline ORGA & 0,71 & 0,0082 & 25,37 & 0,0000 \\
\hline SQ & 0,68 & 0,0074 & 23,87 & 0,0000 \\
\hline DATA & 0,66 & 0,0110 & 14,37 & 0,0000 \\
\hline TECH & 0,74 & 0,0083 & 29,42 & 0,0000 \\
\hline CRM & 0,70 & 0,0085 & 23,25 & 0,0000 \\
\hline
\end{tabular}

Hypothesis H0 is rejected in the five tests ( $\mathrm{p}$-value $=0.0000<0.05$ ). The average score is significantly higher than 0.50 in all five cases.

\section{Conclusion and recommendation}

The major purpose of this study was to examine the impact of customer relationship management on enhancing customer loan acquisition, with ultimately leads to customer satisfaction in commercial banks in Cameroon. The study concluded that, there is a significant positive relationship between loan acquisition by the customers, and the mains CRM dimensions (CRM structure, service quality, customer database, technology based CRM). Among those dimensions, customers' database $86.9 \%$ and technology based CRM 86,4 \% have positive and significant influence on loan decision-making.

As we can see, the research work concluded the positive and significant impact of CRM dimensions on loan satisfaction in the commercial banks in Cameroon. Therefore, commercial banks in Cameroon can achieve more with adapted strategies to capitalize the contribution of above mentioned CRM dimensions on customer satisfaction and also attract the new customers witch can able them to easily win the future challenges.

The recommendation of this study is that, the decision makers of the bank should develop the real strategies of implementation of CRM as means to improve customer's satisfaction, specially concerning loan demand. They should carry out the market intelligence to capture the requirements and desires of customers. They should try to understand and get close to the customer's trough an effective complaints management system in order to enhance the customer-banks relationship.

\section{References}

Abdul Alem, M \& Basri, B,R. (2012). Customer Relationship Management (CRM) in Hotel Industry: A framework Proposal on the Relationship among CRM Dimensions, Marketing Capabilities and Hotel Performance. International Review of Management and Marketing. Vol. 2, No. 4, 2012, pp.220- 230

Akroush, M. N., Dahiyat, S. E., Gharaibeh, H. S., and Abu-Lail, B. N., (2011). Customer Relationship Management Implementation: An Investigation of a Scale's Generalizability and Its Relationship with Business Performance in a Developing Country Context. International Journal of Commerce and Management, 21(2), 158-190.

Baran, R. J., \& Galka, R. J. (2013). CRM: The foundation of contemporary marketing strategy. London: Routledge. Bhattacharya, A. (2011) Preeminent Analysis of Customer Relationship Management (CRM). International Journal of Research in Management \& Technology , 1 (1) ,45-51.

Dehghan, A., Zenouzi, B., \& Albadvi, A. (2012). An Investigation on the Relationship between Service Quality and Customer Satisfaction: In the Case of CCG CO. International Business Research, 5(1), 3-21.

Dowling, G. (2002). Customer Relationship Management: In B2C Markets, Often Less Is More. California Management Review, 44(3), 121-137. https://doi.org/10.2307/41166134

Ergungor S. (2001) The relationship between is i of Contemporary Hospitality Management. 2001;13 ISS(5):213-217.

Eid, R. (2007), Towards a Successful CRM Implementation in Banks: An Integrated Model. The Service Industries Journal, 27(8), 1021-1039. European Journal of Marketing, 39(11/12), 1264-1290. Faed, A. (2010), A conceptual Framework for E-loyalty in Digital Business Environment . 4 1 EEE Dest , 547-552

Farquad,M.A.H.,Ravi,V.,\&Raju,S.B.(2012).AnalyticalCRMinbankingandfinanceusingSVM: A modified active learning-based rule extraction approach. International Journal of Electronic Customer Relationship Management, 6(1), 48-73. https://doi.org/10.1504/IJECRM.2012.046470 


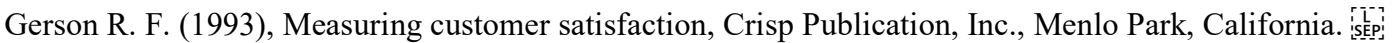

Giannakis, C., \& Boutsouki, C. (2014). Customer relationship management in the era of social web and social customer: an investigation of customer engagement in the Greek retail banking sector. Procedia-Social and Behavioral Sciences, 148(2), 67-78. https://doi.org/10.1016/j.sbspro.2014.07.018

Graf, M., Schlegelmilch, B. B., Mudambi, S. M., \& Tallman, S. (2013). Outsourcing of customer relationship management: Implications for customer satisfaction. Journal of Strategic Marketing, 21(1), 68-81. https://doi.org/10.1080/0965254X.2012.734844

Hayes B. E. (1992), Measuring customer satisfaction: Development and use of questionnaire, ASQC Quality Press,

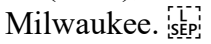

Haridasan, V., \& Venkatesh, D. (2011). CRM Implementation in Indian Telecom Industry - Evaluating the Effectiveness of Mobile Service Providers Using Data Envelopment Analysis. The International Journal of Business Research and Management (IJBRM), 2(3). Retrieved from http://www.amazonaws.com

Hill, N., Brierley, J., \& MacDougall, R. (2013). How to measure customer satisfaction. Burlington, VT, USA: Gower.

Iriqat, R. A., \& Daqar, M. A. A. (2017). The Impact of Customer Relationship Management on Long-term Customers' Loyalty in the Palestinian Banking Industry. International Business Research, 10(11), 139. Retrieved from https://doi.org/10.5539/ibr.v10n11p139

Kärnä, S. (2014). Analysing customer satisfaction and quality in construction-the case of public and private customers. Nordic Journal of Surveying and Real Estate Research, 2(1), 112-116.

Khaligh, A., Miremadi, A., \& Aminilari, M. (2012). The Impact of eCRM on Loyalty and Retention of 90 mas.ccsenet.org Modern Applied Science Vol. 11, No. 12; 2017 Customers in Iranian Telecommunication Sector. International Journal of Business Management, 7(2), 150-162. Retrieved from https://doi.org/10.5539/ijbm.v7n2p150

Khodakarami, F., \& Chan, Y. E. (Khodakarami, F., \& Chan, 2014). Exploring the role of customer relationship management (CRM) systems in customer knowledge creation. Information \& Management, 51(1), $27-$ 42, https://doi.org/10.1016/j.im.2013.09.001

Kocoglu, D (2012). Customer relationship management and customer loyalty; the survey in the sector of banking. International Journal of Business and Social Science Vol. 3 No. 3; February 2012

Muro, M. B., Magutu, P. O., \& Getembe, K. N. (2013). The strategic benefits and challenges in the use of customer relationship management systems among commercial banks in Kenya. European Scientific Journal, ESJ, 9(13), 34-49.

Nazir, S., Khan, S., Jamil, R. A., \& Mehmood, Q. S. (2014). Impact of customer relationship management on customer gratification in hoteling industry. Journal of Management Info, 3(1), 84-98.

Oduro, R., (2013). Factors That Determine Customer Satisfaction Level in Banking Institutions: Evidence from Ghanaian Banking Industry, Asian Journal of Business and Management Sciences. 2 (7): 01-13.

Oliver, R. L. (2014). Satisfaction: A behavioral perspective on the consumer. London: Routledge.

Padmavathy, C., Balaji, M. S., \& Sivakumar, V. J. (2012). Measuring effectiveness of customer relationship management in Indian retail banks. International Journal of Bank Marketing, 30(4), 246-266, https://doi.org/10.1108/02652321211236888

Peltier, J., Zahay, D., \& Krishen, A. S. (2013). A hierarchical IMC data integration and measurement framework and its impact on CRM system quality and customer performance. Journal of Marketing Analytics, 1(1), $32-48$.

Rego, L. L., Morgan, N. A., \& Fornell, C. (2013). Reexamining the market share-customer satisfaction relationship. Journal of Marketing, 77(5), 1-20.

Saad, N. M. (2012). Comparative analysis of customer gratification on Islamic and conventional banks in Malaysia. Asian Social Science, 8(1), 73-88.

Sanjuq, G. (2014). The impact of service quality delivery on customer gratification in the banking sector in Riyadh, Saudi Arabia. International Journal of Business Administration, 5(4), 77-89. Retrieved from https://doi.org/10.5430/ijba.v5n4p77

Sayani,H (2015) "Customer satisfaction and loyalty in the United Arab Emirates banking industry", International Journal of Bank Marketing, Vol. 33 Issue: 3,pp.351375, https://doi.org/10.1108/IJBM-12-2013-0148

SAP AG (2002) “Customer Relationship Management for the Banking Industry” MySAP, White Papers, [Online], Available from: http:/www.sap.com/africa/industries/banking/ pdf/MYSAPCRM.pdf [Accessed 25th March 2008]

Sun, K. A., \& Kim, D. Y. (2013). Does customer satisfaction increase firm performance? An application of 
American Customer Satisfaction Index (ACSI). International Journal of Hospitality Management, 35, 6877. https://doi.org/10.1016/j.ijhm.2013.05.008

Rizan, M. (2010). "Analysis of Service Quality and Customer Satisfaction, and Its Influence on Customer Loyalty". Oxford Business \& Economics Conference Program.

Roch \& Allen (2007) Analysis customer satisfaction and customer loyalty. [i

Vella, J., \& Caruana, A. (2012). Encouraging CRM systems usage: A thesis among bank managers. Management Research Review, 35(2), 121-133. https://doi.org/10.1108/01409171211195152

Winer, R. (2001). A framework for customer relationship management. California Management Review, 43(4), 89-105

Zopounidis, C. (2012). New Trends in Banking Management. Luxembourg, Springer Science \& Business Media. 